\title{
Pengaruh Sumur Injeksi \\ Terhadap Reservoir Panas Bumi Dominasi Air pada Simulasi Lapangan Panas Bumi Dieng Unit II Menggunakan Software Tough-2
}

\author{
Arizona Yoris Wirawan \\ PT. PLN (Persero) \\ Coresponding author. email : yorisarizona17@gmail.com
}

\begin{abstract}
Abstrak
Dieng merupakan salah satu lapangan panas bumi yang sistem reservoirnya didominasi air. Lapangan dengan reservoir dominasi air memerlukan separator untuk memisahkan fasa uap dan fasa cair, karena fluida didominasi air, fasa cair yang dihasilkan tentu lebih banyak daripada fasa gas sehingga perlu dilakukan injeksi untuk menghindari polusi.Kesetimbangan energi merupakan persamaan dengan prinsip dasar bahwa energi yang masuk kedalam suatu sistem sama besarnya dengan energi yang keluar dari sistem tersebut tanpa ada akumulasi. Prinsip ini digunakan untuk menganalisis bagaimana kondisi reservoir panas bumi Dieng di masa lalu sehingga dapat dijadikan pembelajaran untuk kasus serupa di masa sekarang dan masa yang akan datang. Massa yang keluar sistem antara lain dapat berupa manifestasi permukaan seperti fumarole dan hot springs. Proses ekstraksi fluida juga mengurangi massa yang ada dalam sistem. Sedangkan massa yang masuk kedalam sistem dapat berupa injeksi alami dan injeksi. Metodologi penelitian ini, menggunakan prinsip kesetimbangan energi yang disimulasikan dengan bantuan simulator Tough-2. Hasil penelitian dapat menentukan keefektifan injeksi terhadap tekanan reservoir. Kesimpulan pada penelitian ini, bahwa injeksi perlu dilakukan sedini mungkin pada reservoir dominasi air untuk menghindari tekanandrop yang besar di awal produksi. Namun perlu diperhatikan juga posisi sumur injeksi yang akan difungsikan sebagai sistem recharge, karena akan berpengaruh pada temperatur reservoir, khususnya temperatur pada sumur produksi yang terdekat dengan sumur injeksi.
\end{abstract}

Kata kunci : sumur injeksi, reservoir panas bumi, simulasi tough-2

\begin{abstract}
Dieng is one of the geothermal fields where the reservoir sistem is dominated by water. A field with a water domination reservoir requires a separator to separate the vapor phase and liquid phase, because the fluid is dominated by water, the liquid phase produced is certainly more than the gas phase so injection needs to be done to avoid pollution. Energy balance is an equation with the basic principle that the energy that enters a sistem is as large as the energy coming out of the sistem without any accumulation. This principle is used to analyze how the condition of the Dieng geothermal reservoir in the past so that it can be used as learning for similar cases in the present and in the future. The mass that exits the sistem can be in the form of surface manifestations such as fumaroles and hot springs. The fluid extraction process also reduces the mass in the sistem. While the mass that enters the sistem can be either natural injection or injection. The research methodology uses the principle of energy balance simulated with the help of the Tough-2 simulator. Research results can determine the effectiveness of injection of reservoir tekanan. The conclusion of this study, that injection needs to be done as early as possible in the reservoir of water dominance to avoid a large tekanan at the beginning of production. However, it should be noted also that the position of the injection well will function as a recharge sistem, because it will affect the reservoir temperatur, especially the temperatur at the production well closest to the injection well.
\end{abstract}

Keywords: injection wells, geothermal reservoir, tough-2 simulation

\section{Pendahuluan}

Injeksi merupakan bagian dari pengelolaan reservoir. Selain mengisi kembali volume pori batuan dengan air agar penurunan tekanan dalam reservoir tidak terlalu cepat, juga untuk mencegah pencemaran lingkungan contoh polusi kimia dan polusi panas karena brine mengandung ion-ion kimia dan panas apabila dibuang ke lingkungan atau sungai yang terdapat di sekitarnya akan merusak lingkungan dan mematikan makhluk hidup di dalamnya. Semua lapangan di Indonesia, air dan kondensat diinjeksikan kembali, tidak ada yang dibuang ke lingkungan sebagaimana dilakukan di massa lalu pada beberapa lapangan seperti di Wairakei di Selandia Baru dan Ahuchapan di El Savador, yaitu air dari separator dibuang ke sungai dan ke laut.

Strategi injeksi antara lain meliputi pemilihan lokasi sumur injeksi, kedalaman dan temperatur injeksi. Pengalaman pada lapangan Awibengkok Gunung Salak telah menunjukkan bahwa penempatan sumur injeksi di dekat sumur produksi akan mengakibatkan penurunan temperatur yang drastic pada sumur produksi, penurunan tekanan 
reservoir akan menjadi lebih cepat dan dapat mengakibatkan penurunan produksi. Untuk mengatasi permasalahan tersebut harus dicari jarak optimal antara sumur produksi dan sumur injeksi. Keseimbangan jarak akan mengakibatkan keseimbangan pada sistem reservoir. Pada beberapa lapangan, untuk mencegah terjadinya thermal or cold water breakthrough, sumur injeksi dipilih lokasinya di daerah yang temperatur lebih rendah. Biasanya di dekat reservoir, tetapi hal ini mengakibatkan penurunan tekanan di sumur produsi lebih cepat, juga mengakibatkan terbentuknya steam cap pada reservoir. Injeksi dilakukan ke zona lebih dalam daripada reservoir.
Energy Balance adalah metode kesetimbangan energi untuk mengetahui seberapa besar energi yang dapat dibangkitkan. Dengan data energi yang telah dibangkitkan, dapat diperkirakan dimensi reservoir, dalam hal ini adalah volume. Kesetim-bangan energi digabungkan dengan metode heat store atau perhitungan panas yang terkandung pada batuan maupun fluida digunakan untuk menghitung perkiraan volume reservoir. Reservoir digambarkan sebagai sebuah sistem dengan kon-disi bahwa energi yang masuk ke dalam sistem akan sama dengan energi yang keluar sistem.

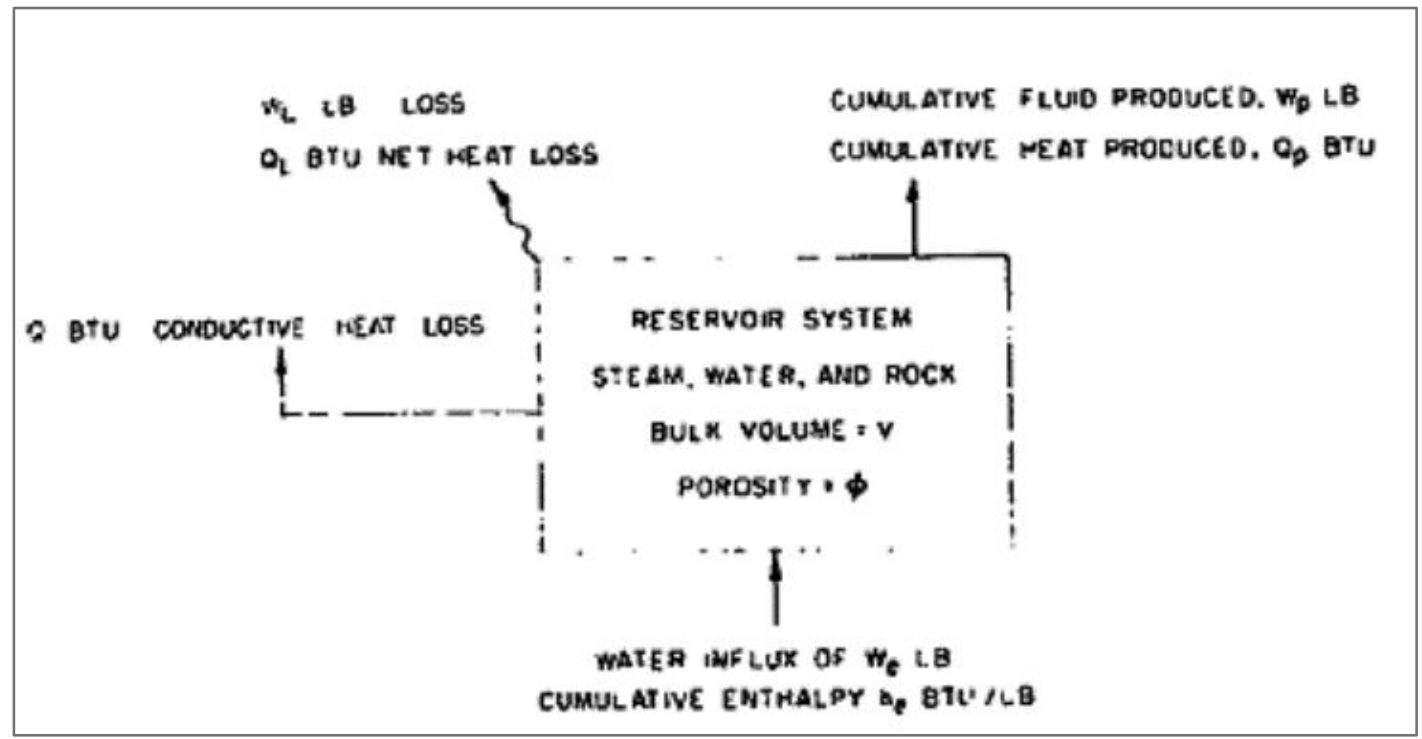

Gambar 1. Skema Siklus Panas dalam Reservoir

Dari Gambar 1 di atas, dapat dilihat bahwa sistem reservoir dikendalikan oleh heat loss baik dari manifestasi maupun proses ekstraksi. Pada penelitian ini, natural recharge diabaikan karena jumlahnya yang sedikit jika dibandingkan dengan jumlah injeksi.

Penurunan tekanan yang terjadi pada reservoir tanpa injeksi maupun dengan injeksi disebabkan oleh proses ekstraksi fluida. Selain itu, manifestasi permukaan juga mengurangi energi yang tersimpan pada reservoir. Seperti dijelaskan pada prinsip kesetimbangan energi, berkurangnya sejumlah massa pada reservoir akan menyebabkan energi pada reservoir berkurang. Energi yang hilang tersebut direpresentasikan dengan berkurangnya tekanan reservoir. Namun, reservoir dengan injeksi mendapatkan bantuan tekanan oleh fluida injeksi, sedangkan reservoir tanpa injeksi tidak mendapatkan suplai tekanan.

\section{Metodologi}

Simulasi pengaruh injeksi pada reservoir panas buemi dilakukan dengan menggunakan simulator dasar diperuntukan untuk aliran multifasa pada media berpori yaitu Tough-2 dengan bantuan Petrasim 7 sebagai interface Tough2.

\section{Hasil dan Pembahasan}

\subsection{Perencanaan Unit 2 sebesar 55 MWe}

Posisi sumur produksi baru yang direncanakan terletak pada di sekitar posisi sumur yang lama. Ada 3 titik lokasi sumurpad dengan total lima sumur baru untuk pengembangan 55 MWe tahap dua pada lapangan panas bumi Dieng, terdapat satu sumur yang menembus patahan, yaitu sumur caldara B. Sedangkan, 4 sumur lainnya sumur caldara C, D, E dan F berada pada kondisi tidak menembus patahan. Kelima sumur yang direncanakan directional tersebut, pada lapisan terbawahnya berada pada lapisan mikrodiorit dengan nilai permeabilitas 
paling tinggi. Ini dimaksudkan untuk mendapatkan flow rate yang diinginkan dengan menjaga sistem panas bumi yang ada pada lapangan panas bumi Dieng tersebut tidak terjadi under saturated maupun superheated, dengan kata lain sistem tersebut dapat suistanable (menjaga kondisi $\mathrm{P}, \mathrm{T}$, Entalpi dan saturasi). Untuk Sumur Caldara B, total massa yang akan diproduksi adalah sebesar 79 $\mathrm{kg} / \mathrm{s}$.

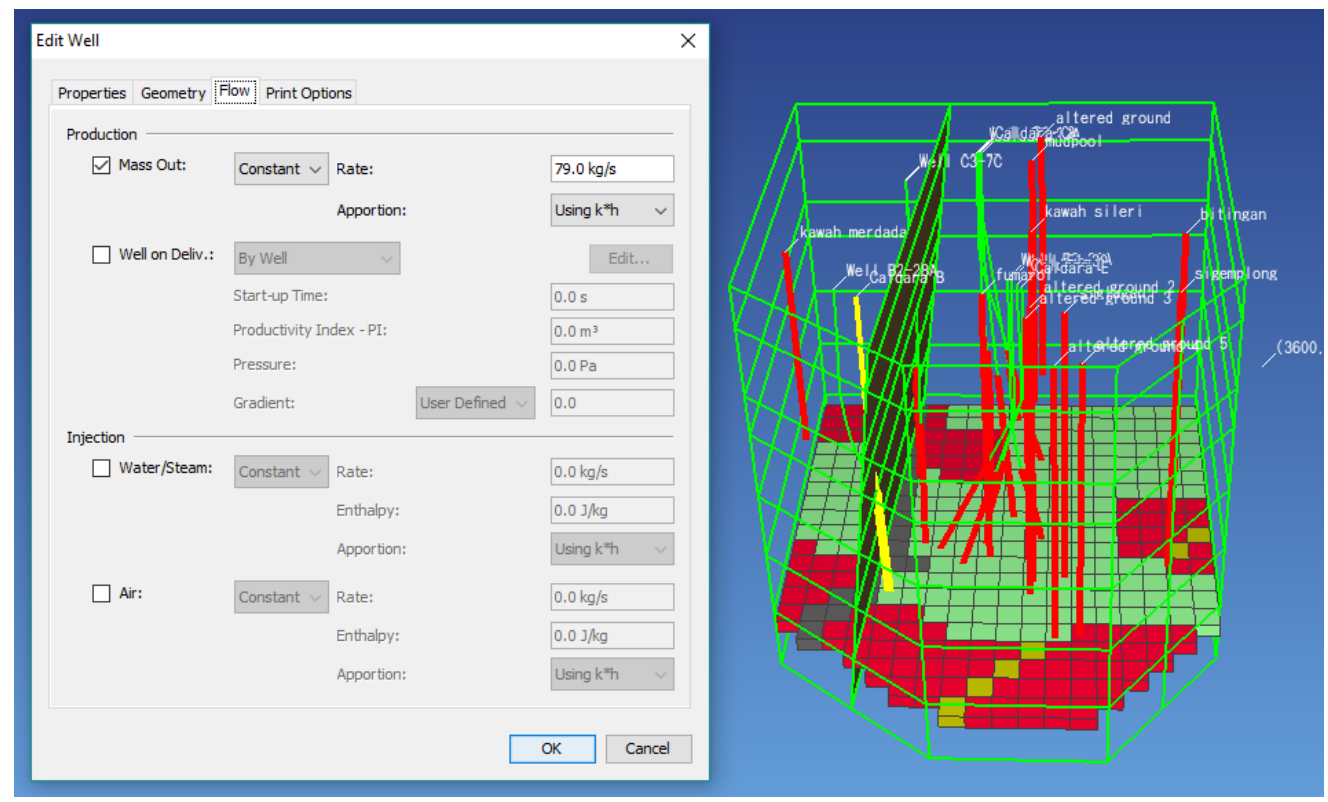

Gambar 2. Flow Rate Sumur Caldara B Dan Bentuk Sumur yang Menembus Patahan

Output hasil running, dapat kita lihat beberapa parameter untuk kemudian data tersebut digunakan untuk perhitungan surface facilities, diantaranya :

- Temperatur pada formasi

- Tekanan pada formasi

- Entalpi
- Sumur Geometry

- Flow Rate

Berikut akan ditampilkan grafik untuk beberapa parameter tersebut diatas pada Sumur Caldara B dengan flow rate $79 \mathrm{~kg} / \mathrm{s}$

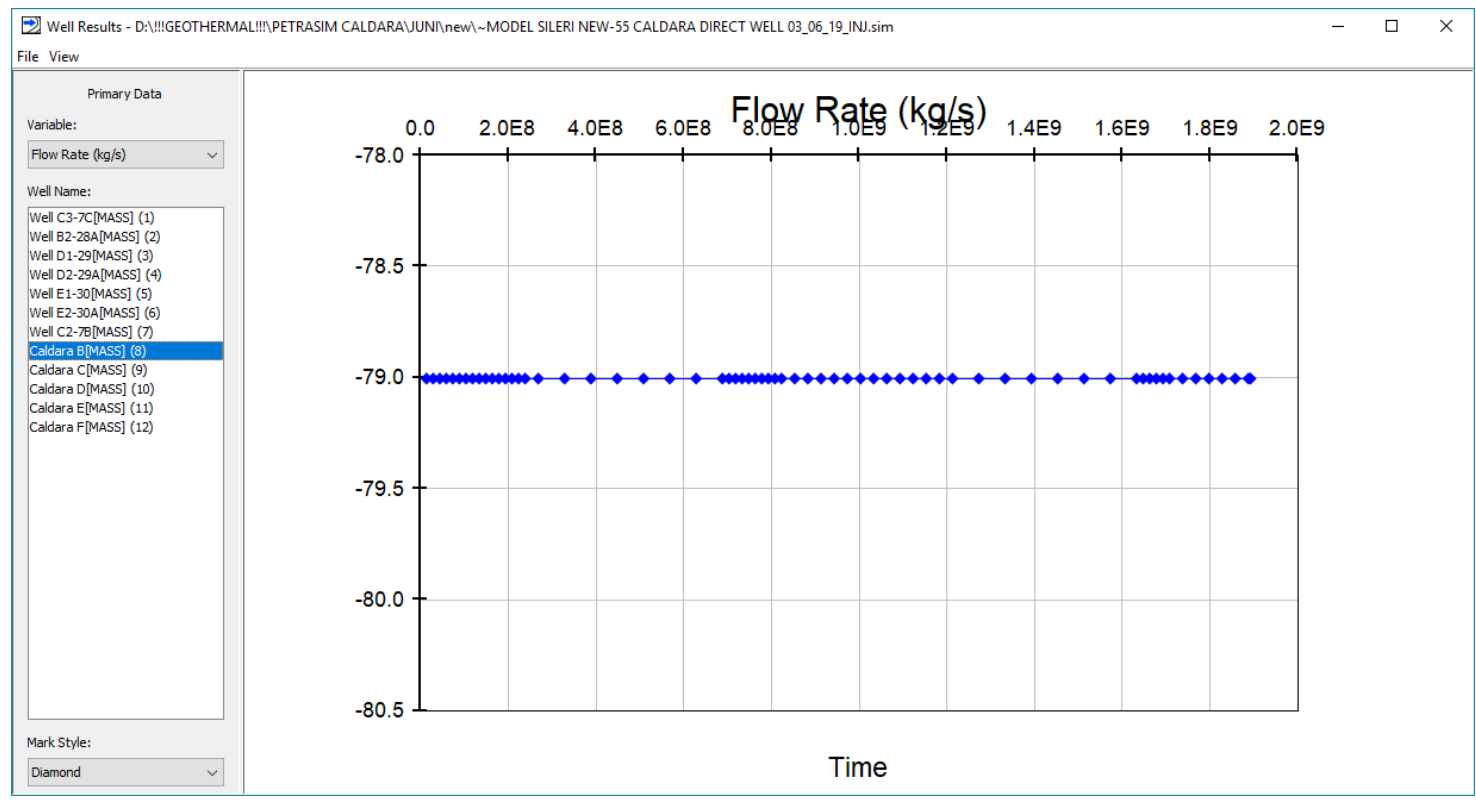

Gambar 3. Flow Rate Sumur Caldara B 
Pengaruh Sumur Injeksi Terhadap Reservoir Panas Bumi Dominasi Air pada Simulasi Lapangan Panas Bumi Dieng Unit II Menggunakan Software Tough-2

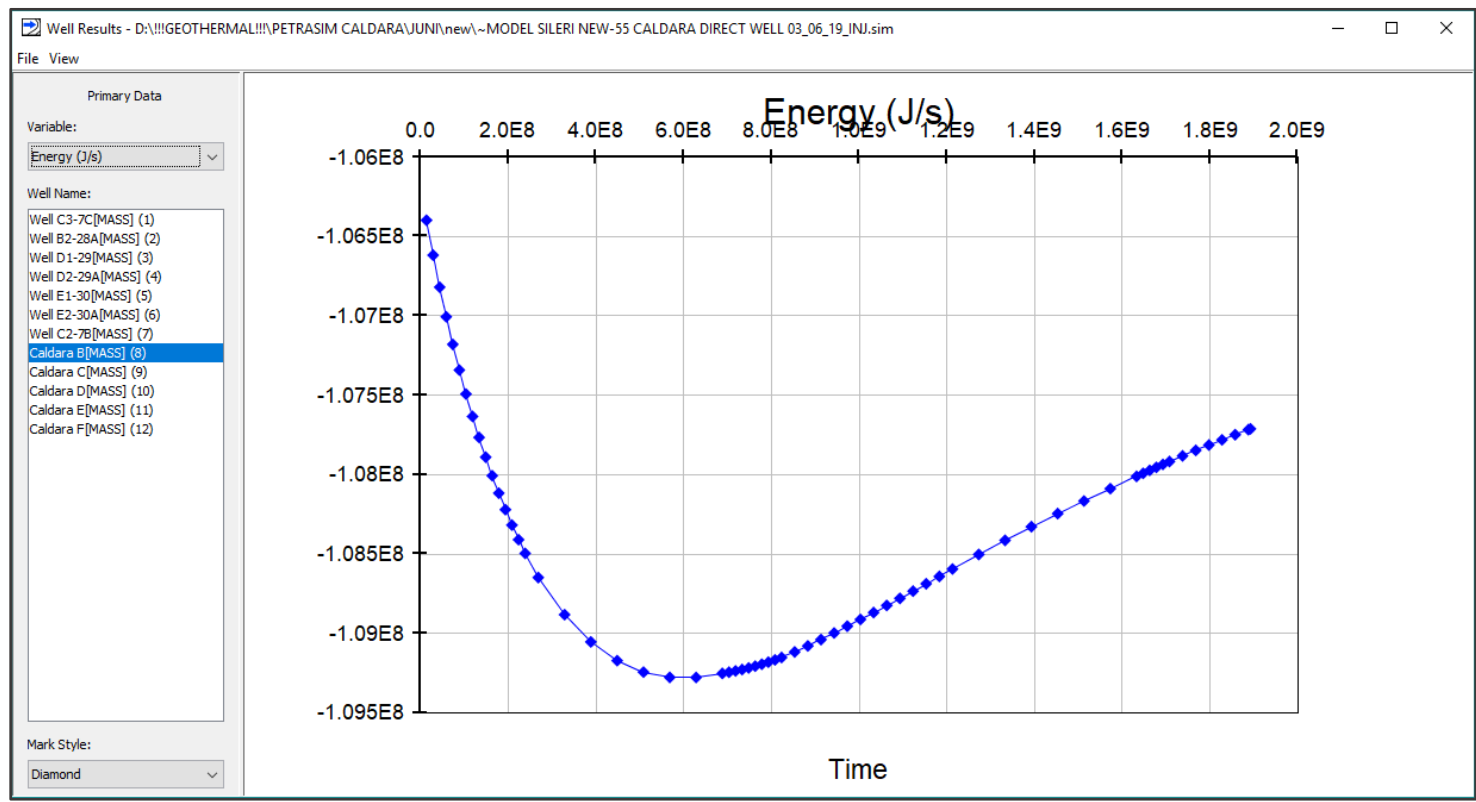

Gambar 4. Energi Sumur Caldara B

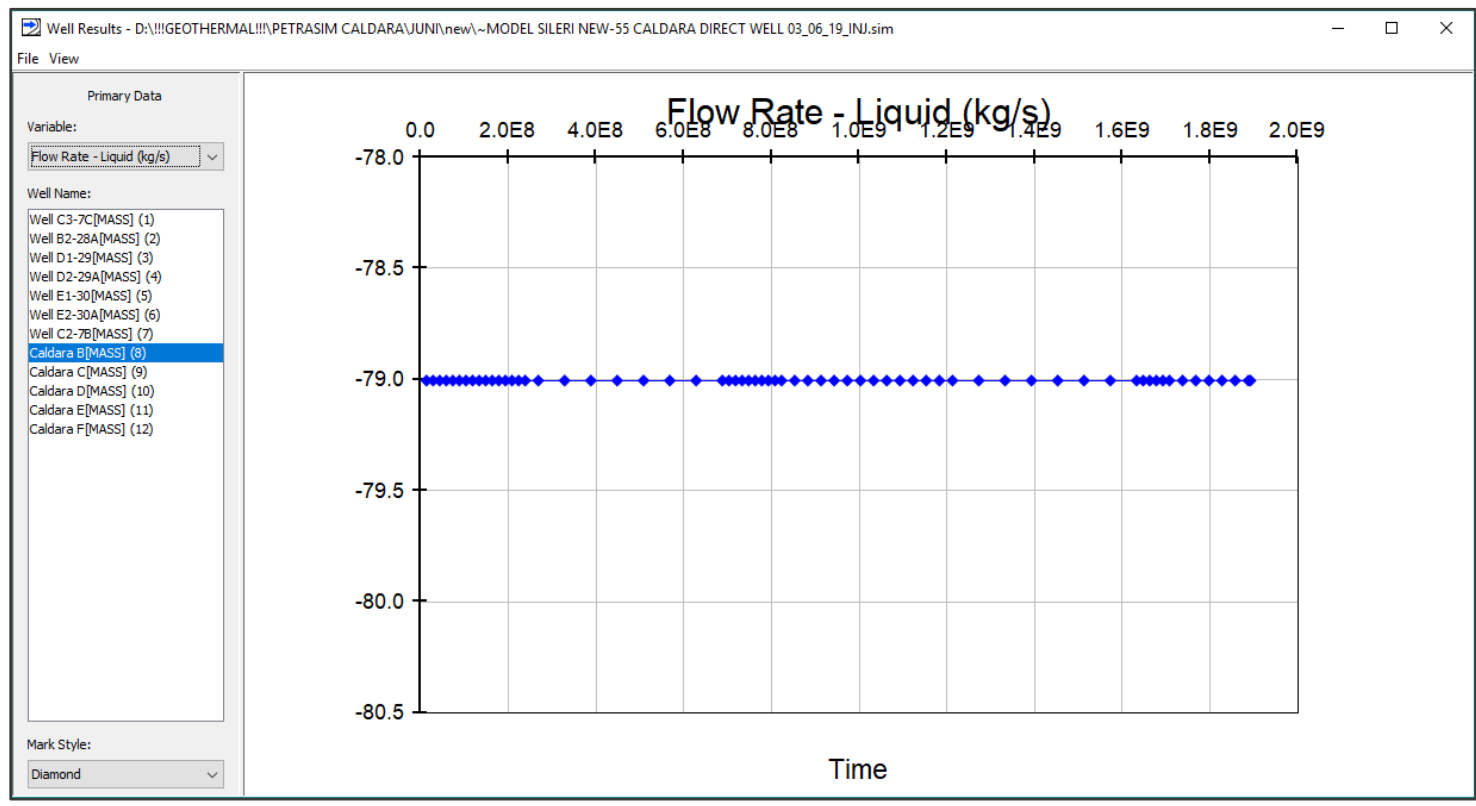

Gambar 5. Flow Rate Liquid Sumur Caldara B 


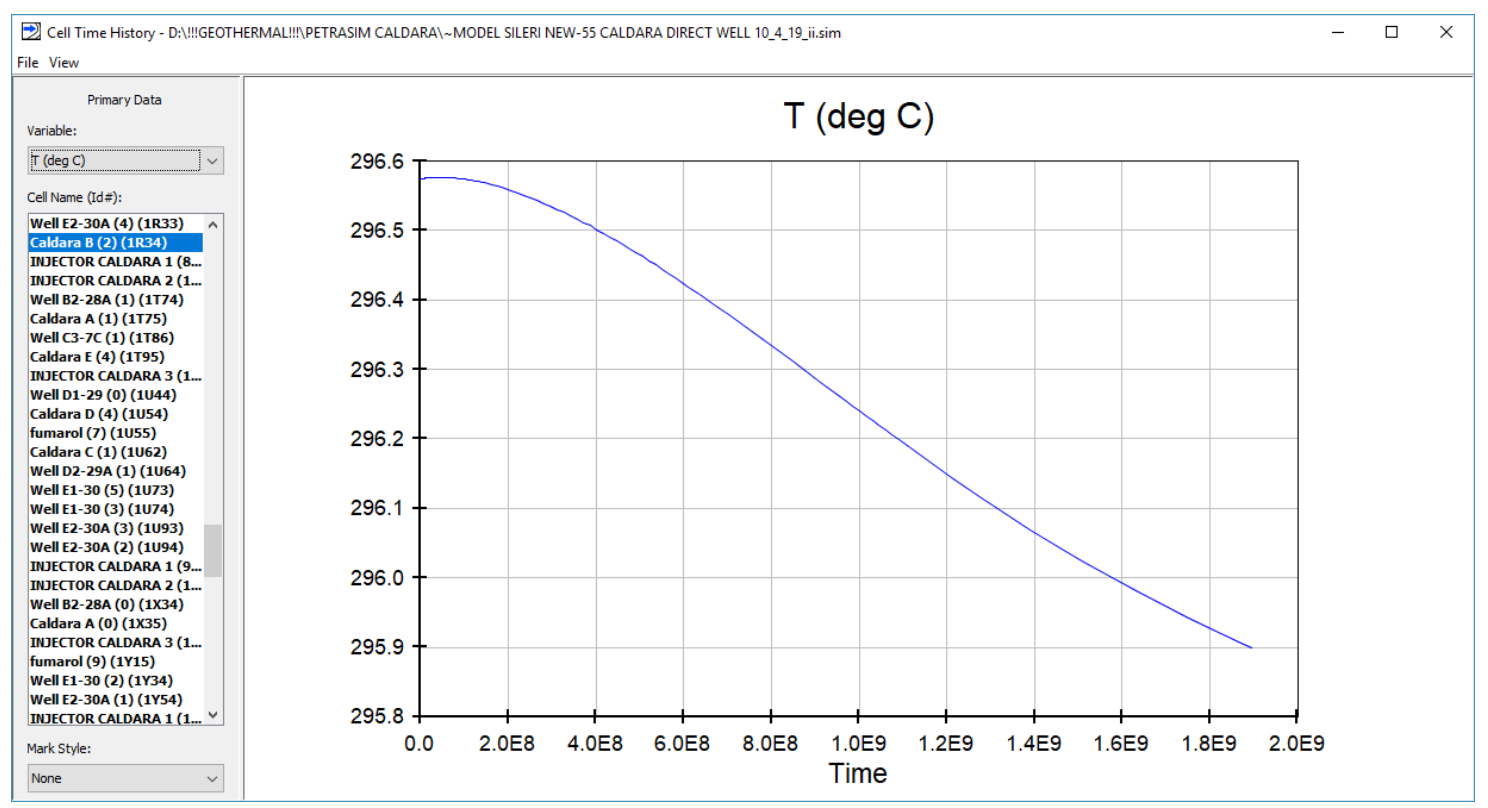

Gambar 6. Temperatur Sumur Caldara B

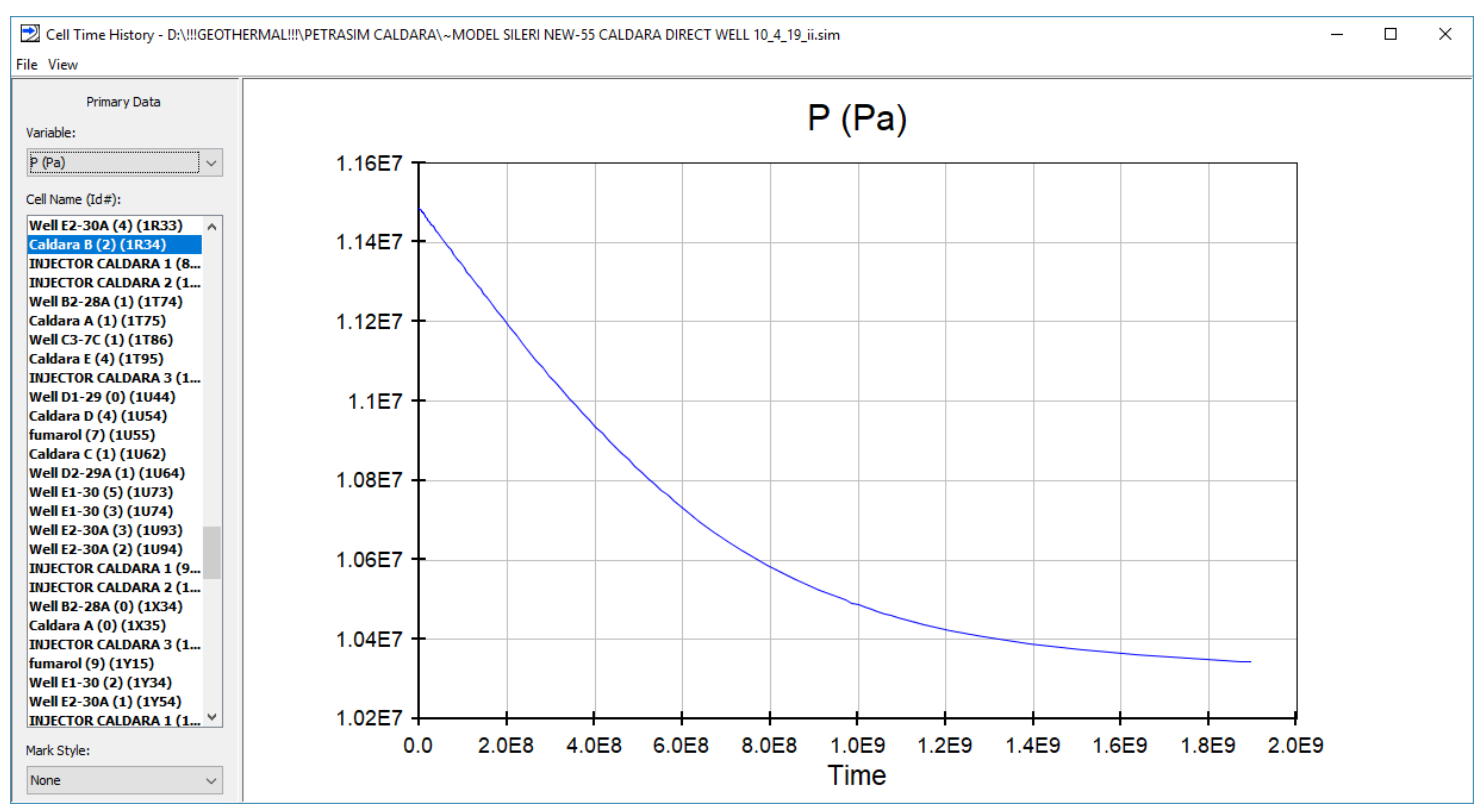

Gambar 7. Tekanan Sumur Caldara B

Setelah semua data telah diisi, terutama parameter pada penambahan sumur, Tough-2 di running dengan kondisi 60 tahun, untuk mengetahui bebe-rapa parameter selama 60 tahun seperti temperatur, tekanan, entalpi dan saturasi. Berikut rincian data perencanaan 5 sumur baru yang telah di running selama 60 tahun.

Tabel 1. Rekap Data Lima Sumur Baru PLTP Unit 2 Dieng

\begin{tabular}{|r|l|r|r|r|r|r|r|}
\hline NO WELL & NAMA WELL & $\begin{array}{c}\text { FLOW RATE } \\
(\mathbf{K G} / \mathbf{S})\end{array}$ & $\begin{array}{c}\text { Steam Massa } \\
\mathbf{( k g / s )}\end{array}$ & TEMPERATURE $\left({ }^{\circ} \mathbf{C}\right)$ & PRESSURE (Bar) & ENTALPI (kJ/kG) & SATURASI \\
\hline 1 & CALDARA B & 79 & 21.555545 & 305.00 & 161.30 & $1,352.00$ & 1.00 \\
\hline 2 & CALDARA C & 61 & 15.753433 & 305.00 & 173.70 & $1,353.00$ & 1.00 \\
\hline 3 & CALDARA D & 77 & 18.896955 & 300.00 & 158.50 & $1,348.00$ & 1.00 \\
\hline 4 & CALDARA E & 62 & 15.139408 & 308.00 & 159.00 & $1,355.00$ & 1.00 \\
\hline 5 & CALDARA F & 51 & 11.7555 & 308.00 & 159.30 & $1,353.00$ & 1.00 \\
\hline
\end{tabular}




\section{Pengaruh Sumur Injeksi Terhadap Reservoir Panas Bumi Dominasi Air pada Simulasi Lapangan Panas Bumi Dieng Unit II Menggunakan Software Tough-2}

Flow rate pada masing-masing sumur yang baru disesuaikan (dikondisikan) dengan sumur exsisting. Sehingga nilai rata-rata beragam disesuaikan dengan kondisi reservoir (pada simulasi tough 2). Besar kecilnya nilai flow rate juga harus dipertimbangkan guna mendapatkan sistem panas bumi yang suistanable.

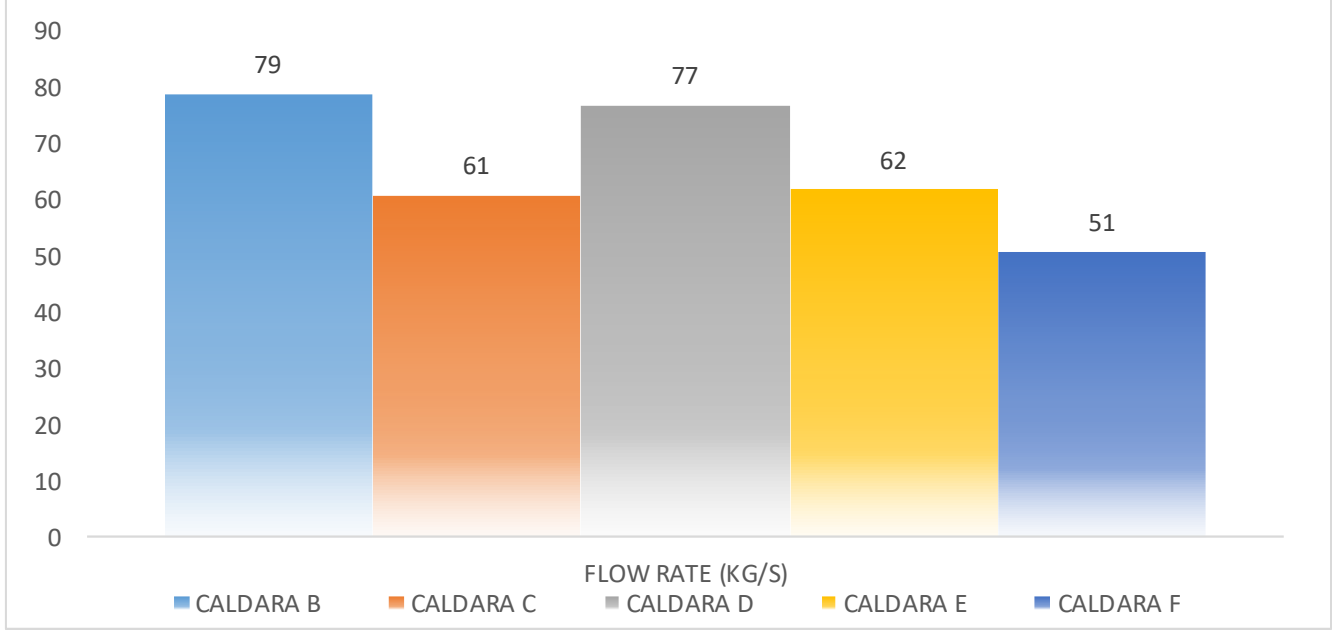

Gambar 8. Grafik Flow Rate Per Sumur Lapangan Dieng Unit 2

Dengan total flow rate yang telah direncanakan yaitu sebesar $330 \mathrm{~kg} / \mathrm{s}$, diyakini mampu membangkitkan atau memproduksi PLTP Tahap 2 sebesar 55 MWe ditambah $10 \%$ margin steam dan rate untuk keperluan injektor sebesar 28 ton/jam.
Di bawah ini kondisi tekanan dan suhu pada sumur exsisting setelah ditambah 5 sumur baru untuk pengembangan 55 MWe tahap dua pada lapangan panas bumi Dieng.

Tabel 2. Data PLTP Unit 1 Dieng

\begin{tabular}{|r|l|r|r|r|r|r|}
\hline NO WELL & NAMA WELL & $\begin{array}{r}\text { FLOW RATE } \\
\text { (KG/S) }\end{array}$ & \multicolumn{2}{|c|}{ TEMPERATURE ( ${ }^{\circ} \mathbf{C}$ ) } & \multicolumn{2}{c|}{ PRESSURE (Bar) } \\
\hline & & & \multicolumn{1}{|c|}{ BEFORE } & \multicolumn{1}{c|}{ AFTER } & \multicolumn{1}{c|}{ BEFORE } & \multicolumn{1}{c|}{ AFTER } \\
\hline 1 & B2 28 A & 76,98 & 308,00 & 308,00 & 90,40 & 90,40 \\
\hline 2 & C2 7B & 7,42 & 323,00 & 323,00 & 130,20 & 127,00 \\
\hline 3 & C3 7C & 37,24 & 309,50 & 314,20 & 104,00 & 119,00 \\
\hline 4 & D1 29 & 34,49 & 322,50 & 319,40 & 96,00 & 91,00 \\
\hline 5 & D2 29 A & 31,51 & 312,00 & 315,00 & 101,00 & 104,00 \\
\hline 6 & E1 30 & 106 & 292,00 & 292,00 & 83,00 & 83,00 \\
\hline 7 & E2 30A & 81,2 & 285,00 & 288,00 & 88,00 & 85,00 \\
\hline
\end{tabular}

Melihat kondisi tekanan dan suhu pada sumur yang sudah ada, memang terjadi perubahan pada sebagian sumur. Namun perubahan ini tidak menunjukkan hasil yang signifikan yang berdampak pada kondisi PLTP yang sudah ada. Sebagian sumur juga ada yang tidak berubah baik itu tekanan maupun suhunya, seperti pada sumur B2 28 A dan E1 30 dengan flow rate masing-masing 76,98 kg/s dan 106 kg/s.Berikut grafik kondisi flow rate pada masing-masing sumur eksisting setelah adanya penambahan 5 sumur baru. 


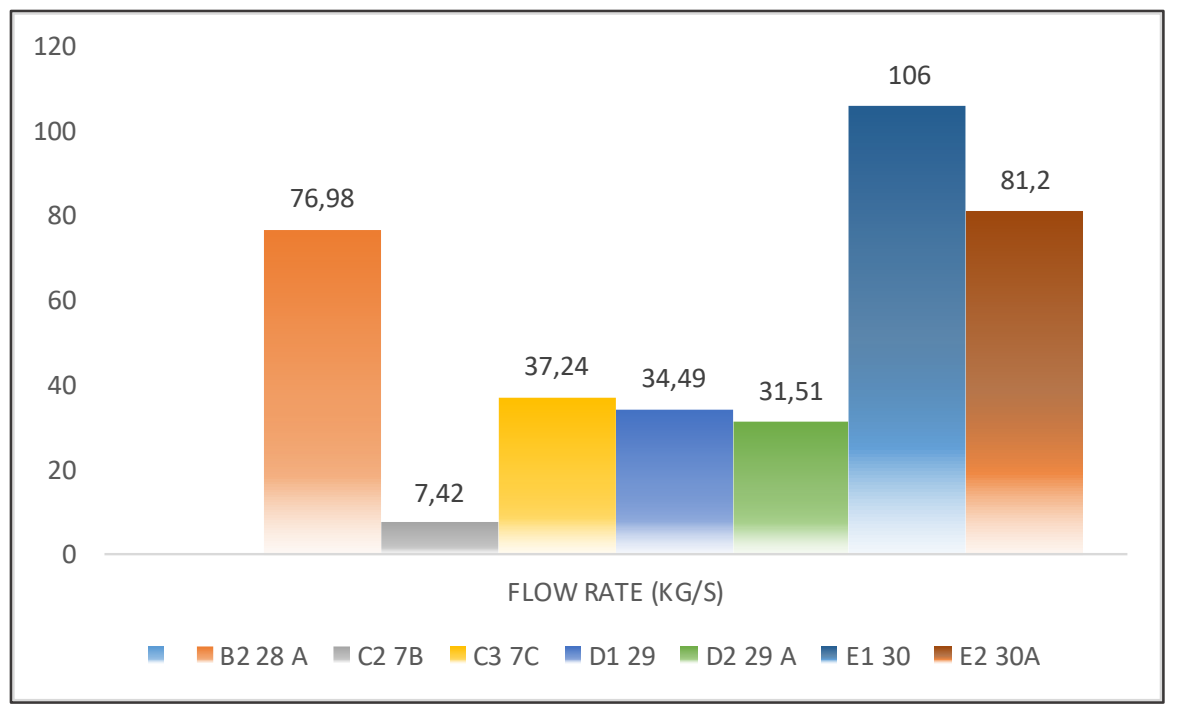

Gambar 9. Grafik Flow Rate Per Sumur Unit 1 Dieng

Hasil yang diperoleh dari hasil simulasi tough-2 (penggabungan file foft dan goft) untuk mengetahui beberapa parameter terhadap fungsi waktu, yaitu :

- Tekanan, bar

- Temperatur, deg C

- Entalpi,kJ/kg dan

- Potential Daya Elektrik, MWe

Dari hasil simulasi, menunjukkan bahwa nilai tekananmengalami penurunan saat pertama di produksi, bersamaan antara Unit 1 Dieng dan Unit
2 Dieng. Dapat dilihat pada grafik di bawah, setelah mengalami penurunan pada Tahun pertama, kemu-dian setelahnya mengalami kenaikan menjelang tahun ke-2 hingga tahun ke-25. Tekanan mengalami kondisi stabil setelah tahun ke-25 hingga tahun ke-60. Kondisi tekanan pada formasi atau pada kondisi feedzone (mulut sumur) berkisar sekitar 185.26 bar. Dapat dikatakan bahwa kondisi tekanan pada formasi cukup stabil dan bagus untuk pengembangan PLTP Unit-2 Dieng. Grafik dapat dilihat pada Gambar 10.

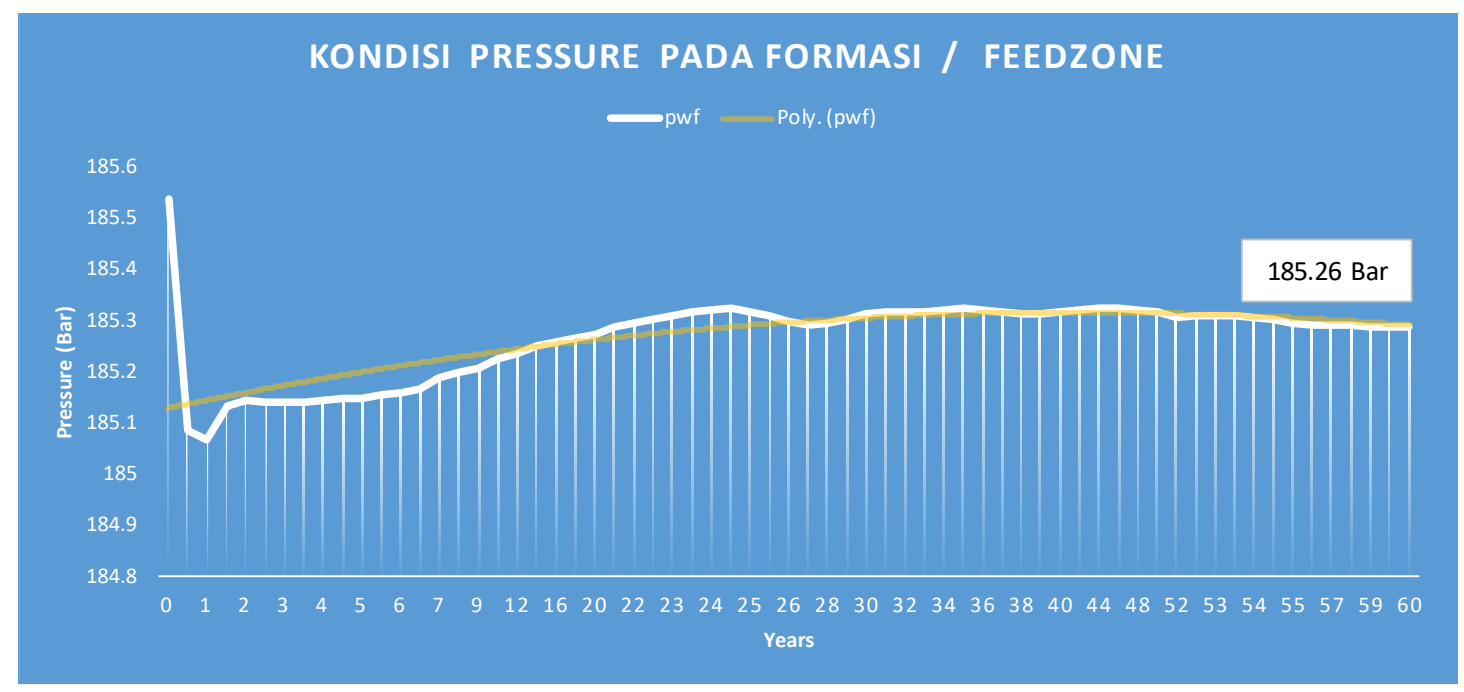

Gambar 10. Grafik Tekanan Terhadap Fungsi Waktu pada Formasi untuk Sumur Caldara B

Pun sama halnya dengan kondisi temperatur pada formasi maupun feedzone, walaupun mengalami penurunan, namun penurunannya tidaklah signifikan. Pada tahun pertama, kondisi temperaturnya berkisar $338^{\circ} \mathrm{C}$ dan stabil pada kondisi $333-334^{\circ} \mathrm{C}$. salah satu keuntungan pada reservoir water dominated adalah kondisinya lebih suistanable (tidak perlu injeksi) untuk mempertahankan kondisi pada reservoir dengan jangka watu yang lama. 
Pengaruh Sumur Injeksi Terhadap Reservoir Panas Bumi Dominasi Air pada Simulasi Lapangan Panas Bumi Dieng Unit II Menggunakan Software Tough-2

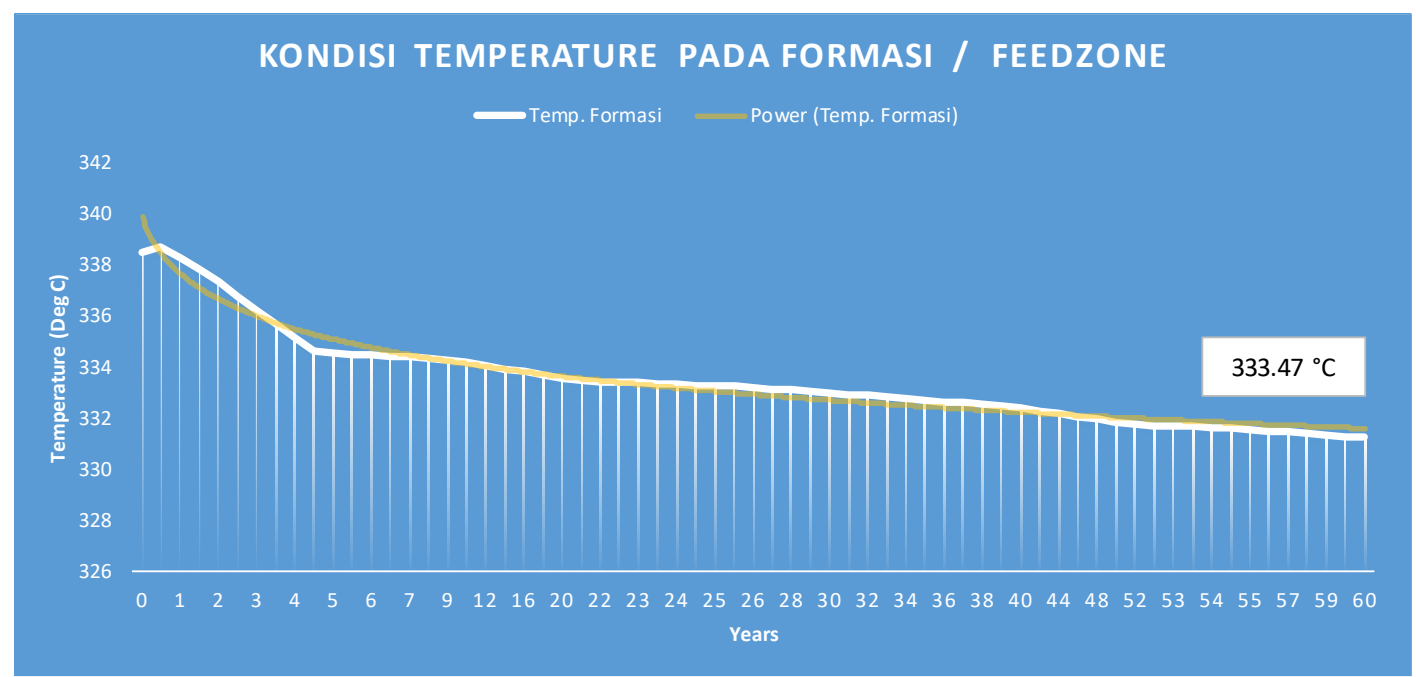

Gambar 11. Grafik Temperatur Terhadap Fungsi Waktu Pada Formasi Sumur Caldara B

Nilai entalpi sangat mempengaruhi daya yang mampu dibangkitkan oleh suatu lapangan panas bumi. Dari perencaan 5 sumur pada simulasi tough2, nilai enthalpi mengalami penurunan mulai awal produksi hingga tahun kelima. Kemudian megalami penurunan secara perlahan mulai tahun ke-6 dan mengalami kondisi stabil pada tahun ke28. Grafik enthalpi terhadap fungsi waktu dapat dilihat pada Gambar 12.

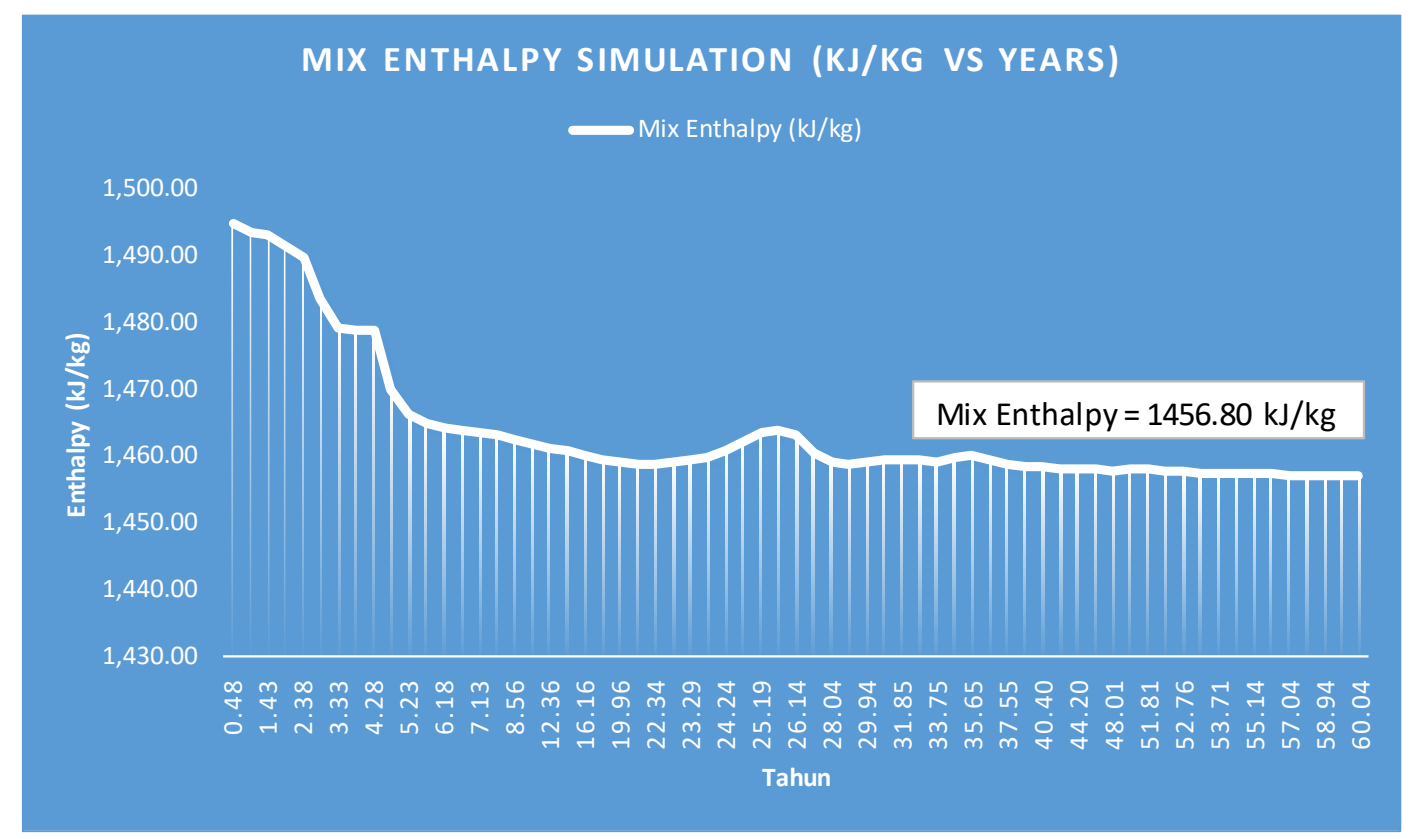

Gambar 12. Grafik Mix Entalpi Fungsi Waktu pada Sumur Caldara B

\subsection{Pengaruh Sumur Injeksi}

Pengaruh sumur injeksi pada reservoir water dominated tidaklah banyak berpengaruh. Namun untuk menjaga kondisi reservoir tetap suistanable, peranan sumur injeksi akan behasil secara positif apabila letak dan jumlah rate yang dipompakan ke dalam reservoir tepat sasaran. Karena apabila salah dalam menentukan, maka kondisi reservoir akan mengalami penurunan kualitas. Idealnya untuk menjaga kesetimbangan energi, yaitu flow rate yang diproduksi sama dengan flow rate yang di injeksikan ke dalam reservoir. Dalam kasus ini akan dicoba beberapa jumlah massa air yang telah dipisahkan oleh separator untuk diinjeksikan kembali ke reservoir. 


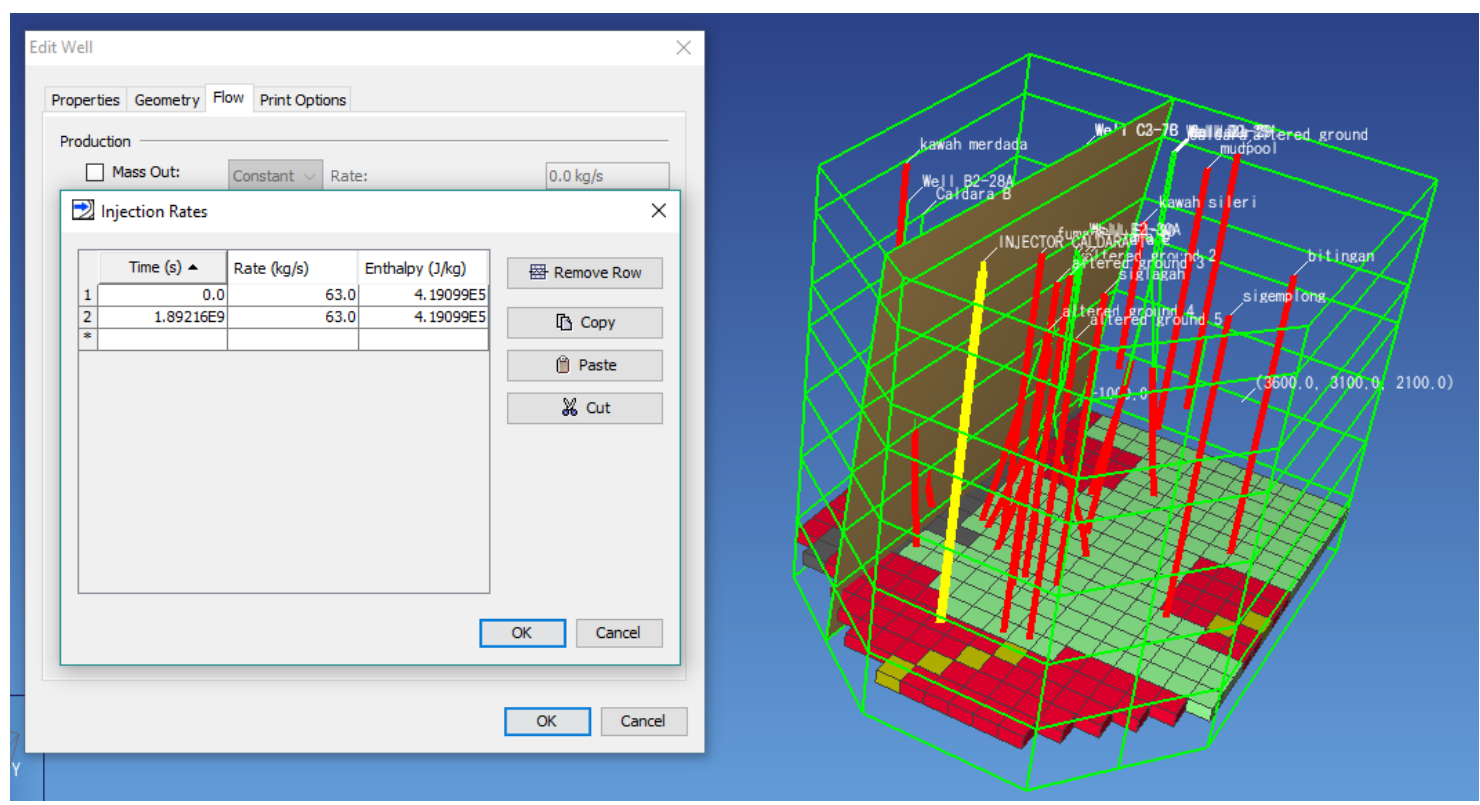

Gambar 13. Letak Posisi Sumur Injeksi Dengan Jumlah Flow Rate 63 Kg/S

Peletakan sumur injeksi yang baik adalah pada lapisan dengan permeabilitas yang rendah. Hasil running simulasi setelah injeksi dengan parameter sebagai berikut :

Flow rate injeksi $: 63 \mathrm{~kg} / \mathrm{s}$
Temperatur $: 80{ }^{\circ} \mathrm{C}$
Waktu Injeksi : 30 tahun
Entalpi $\quad: 419.099 \mathrm{~J} / \mathrm{kg}$

Dapat dilihat pada Gambar 14

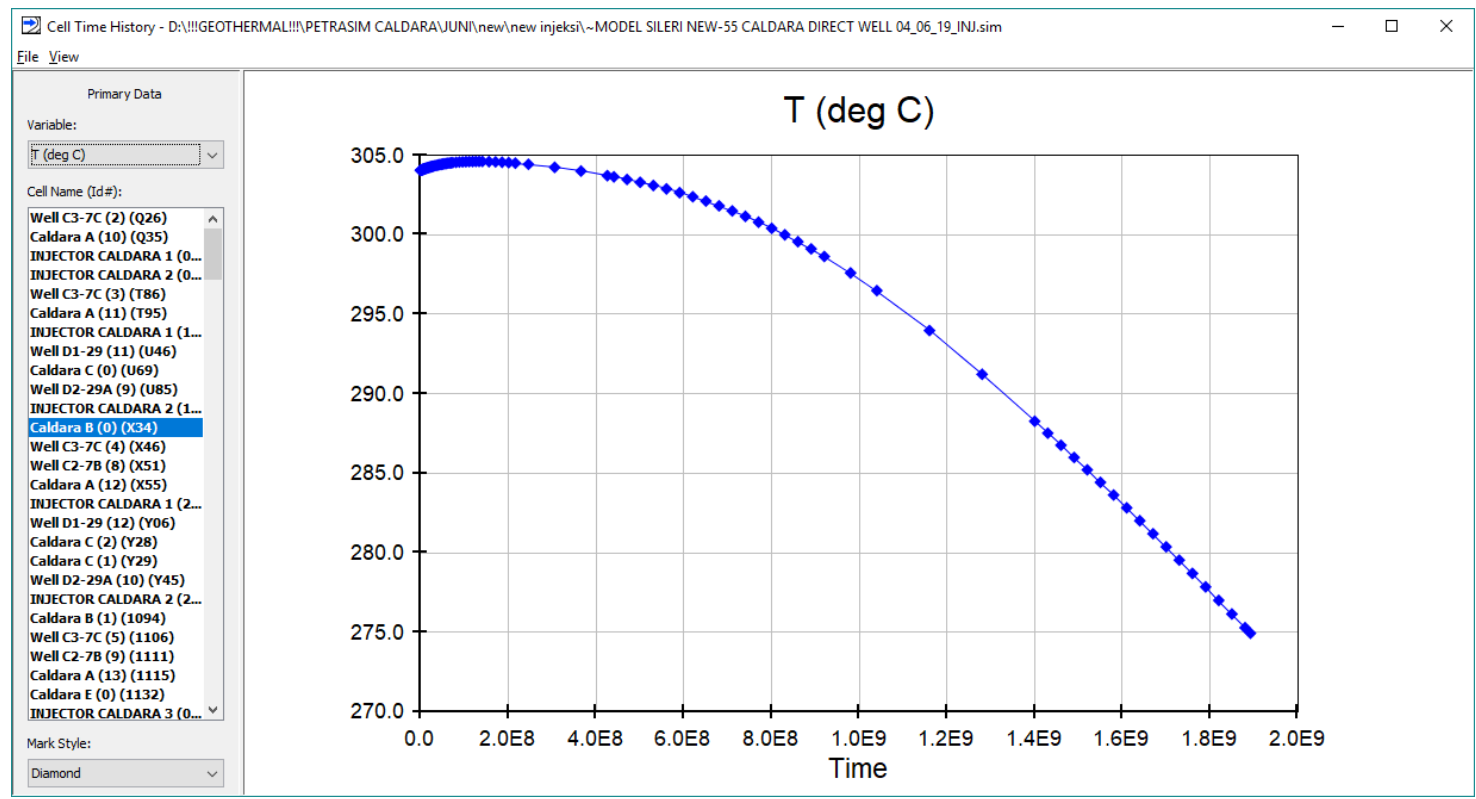

Gambar 13. Penurunan Temperatur Pada Sumur Caldara B

Diantara 5 sumur yang paling terpengaruh adalah Sumur Caldara B, karena posisi sumur injeksi yang lebih dekat dengan Sumur Caldara B daripada sumur yang lain . Semakin besar jumlah air yang diinjeksikan ke dalam reservoir, maka semakin besar juga penurunan temperatur dalam reservoir. Grafik Pengaruh Injeksi Pada Temperatur Formasi Sumur Caldara B Selama 60 tahun dapat dilihat pada Gambar 14. 
Pengaruh Sumur Injeksi Terhadap Reservoir Panas Bumi Dominasi Air pada Simulasi Lapangan Panas Bumi Dieng Unit II Menggunakan Software Tough-2

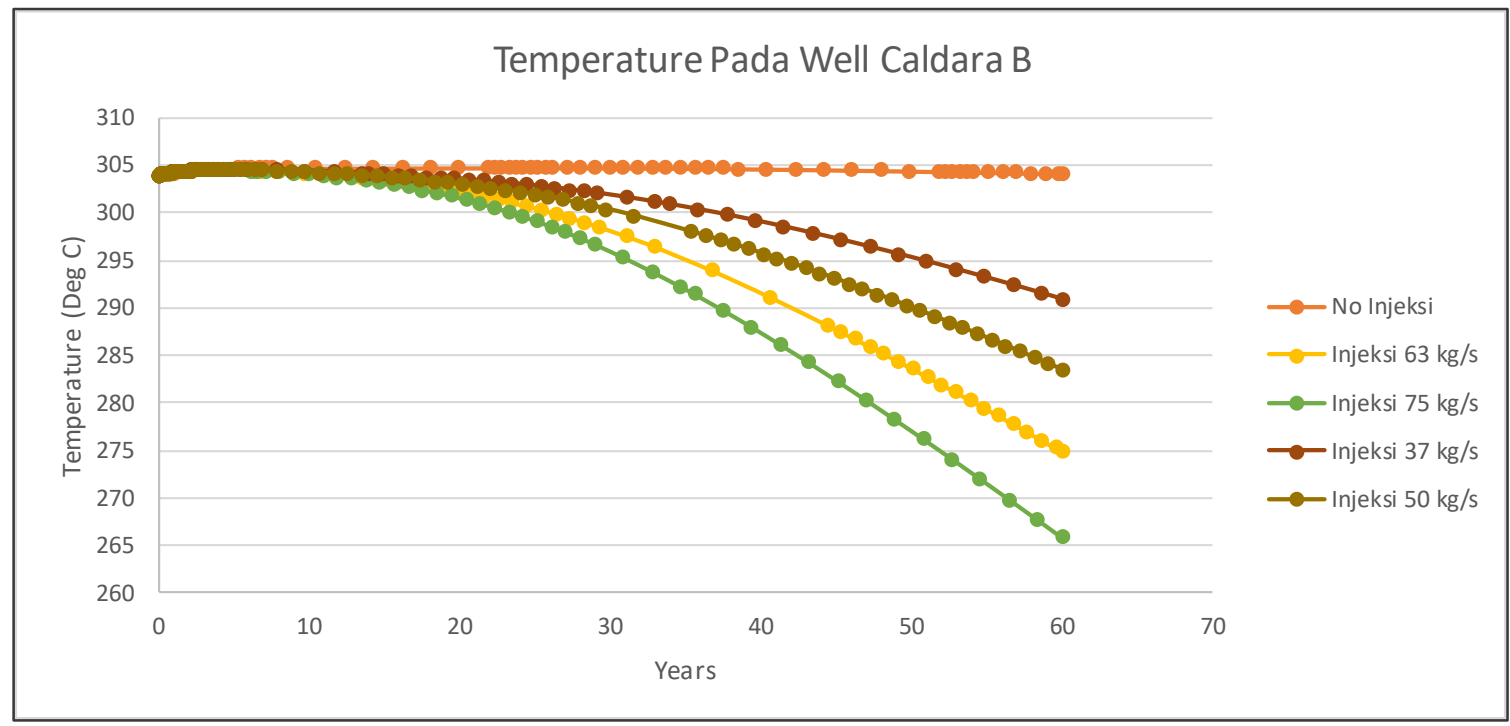

Gambar 14. Grafik Pengaruh Injeksi Pada Temperatur Formasi Sumur Caldara B Selama 60 tahun

Lama injeksi selama 30 tahun dengan total waktu running simulasi selama 60 tahun. Dapat dilihat pada grafik di atas, semakin besar massa air yang diinjeksikan ke dalam reservoir, semakin besar penurunannya. Namun selama kondisi temperatur reservoir masih diatas $250^{\circ} \mathrm{C}$, maka injeksi dalam massa yang besar dapat dilakukan.

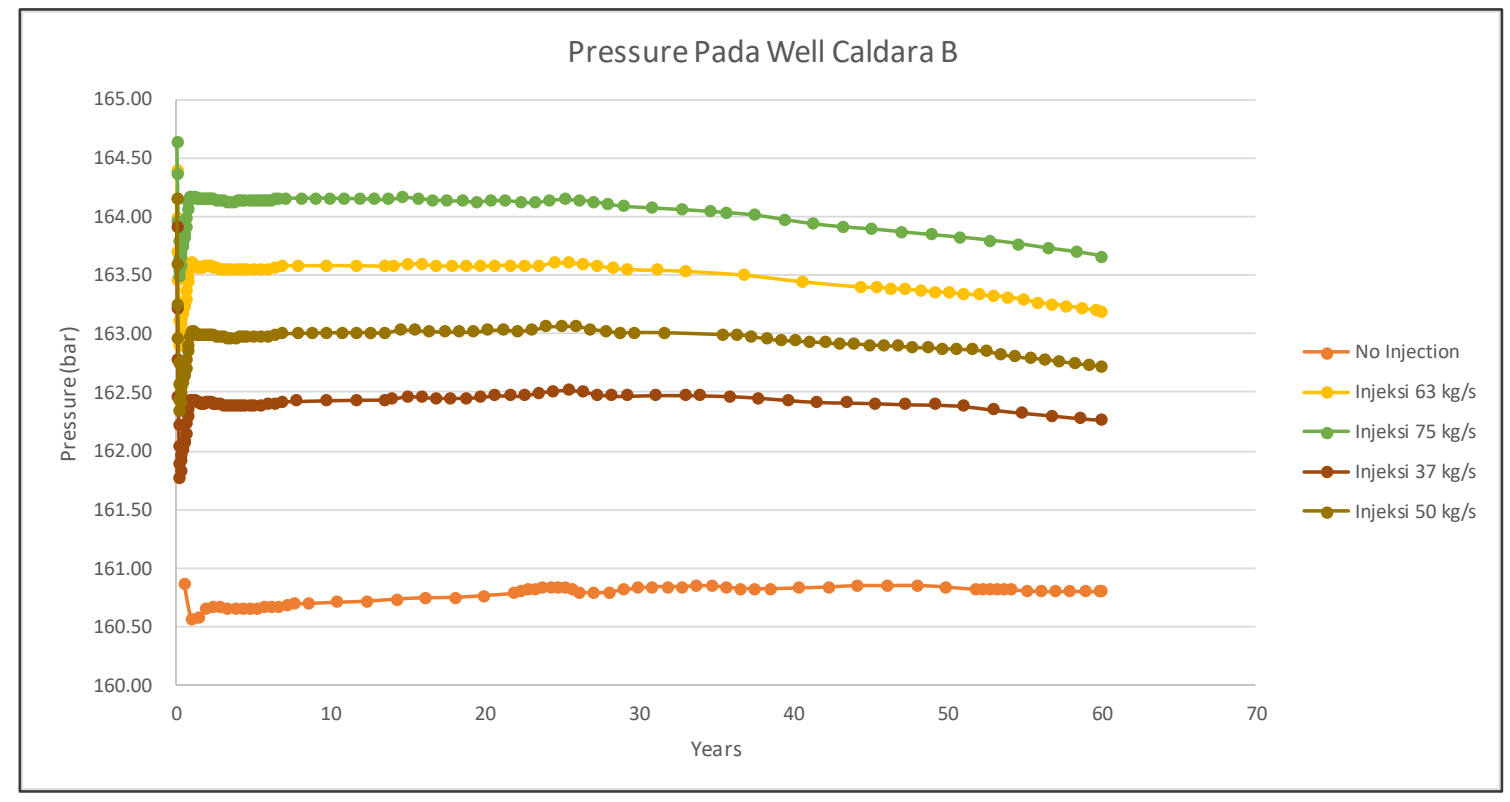

Gambar 15. Grafik Pengaruh Injeksi Pada Tekanan Formasi Sumur Caldara B Selama 60 Tahun

Sedangkan untuk kondisi tekanan, sema-kin besar injeksi ke dalam reservoir maka tekananpada reservoir juga semakin besar. Dapat dilihat pada grafik di atas, selisih antara tanpa injeksi dengan yang diinjeksi $75.6 \mathrm{~kg} / \mathrm{s}$ berkisar 3 sampai 4 bar. Tekanan untuk tanpa injeksi stabil pada nilai 160.75 bar dan untuk injeksi $75.6 \mathrm{~kg} / \mathrm{s}$ tekanannya stabil pada kondisi 163.75 bar dapat dilihat pada Gambar 15.
Dengan adanya perubahan nilai tekanan dan temperatur pada kondisi tanpa injeksi dan dengan injeksi, tentunya ini akan mempengaruhi nilai entalpi-nya juga. Apabila nilai entalpi-nya berubah, maka potensial daya yang mampu dibangkitkan juga akan berubah ditunjukkan pada Gambar 16. 


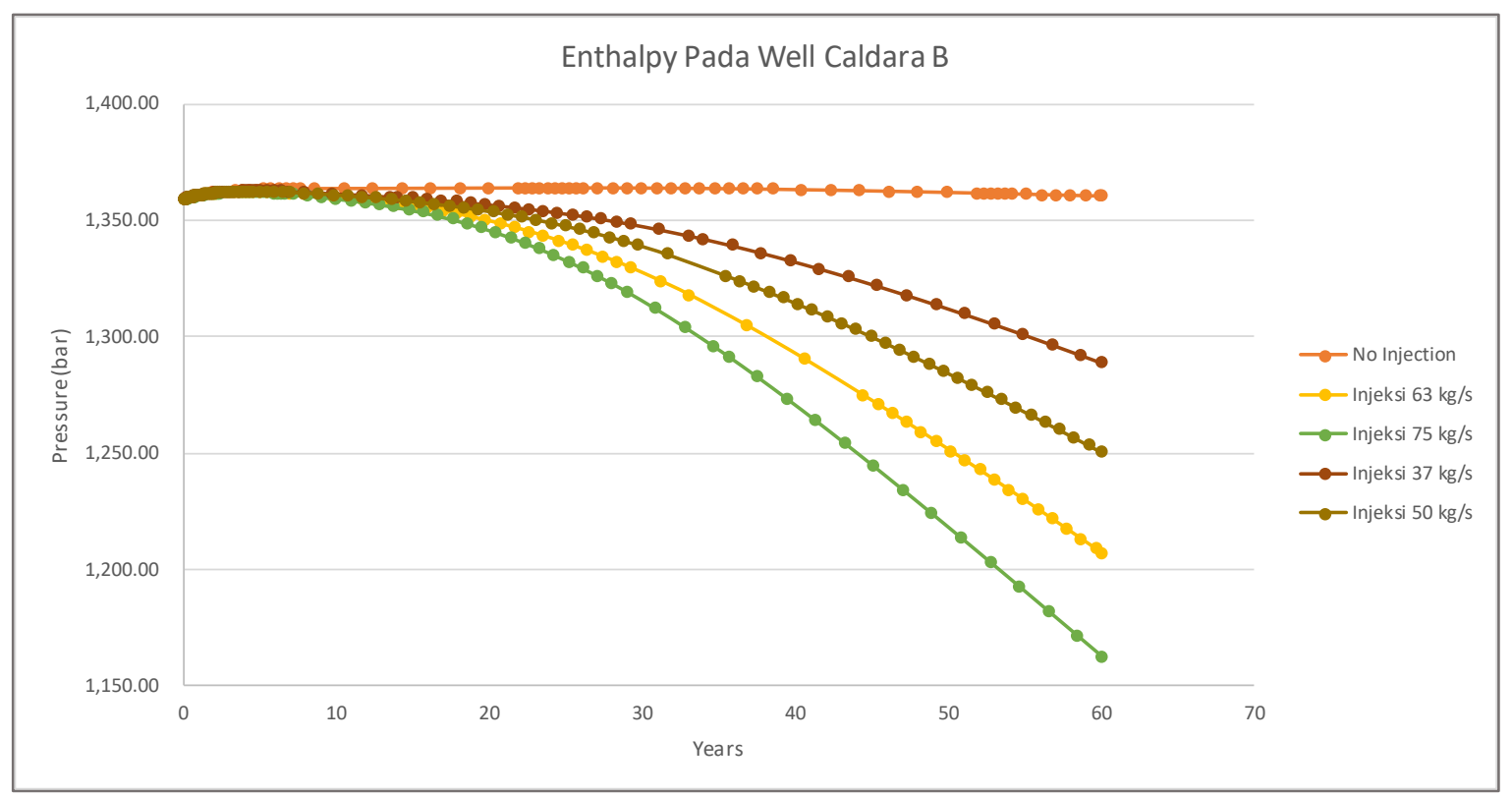

Gambar 16. Grafik Pengaruh Injeksi terhadap Entalpi Sumur Caldara B selama 60 tahun

Dapat dilihat pada grafik diatas, pengaruh injeksi sangat berpengaruh terhadap nilai entalpi, semakin besar massa liquid yang diinjeksikan ke dalam reservoir, maka semakin berpengaruh terhadap penurunan nilai entalpi. Oleh karena itu, perlu di analisa lebih lanjut secara optimal agar dalam perencanaan total massa liquid yang akan diinjeksikan ke dalam reservoir tidak membuat nilai entalpi semakin kecil atau membuat temperatur di dalam reservoir semakin rendah.

\section{Kesimpulan}

1. Injeksi di Lapangan Panas Bumi Dua Fasa Dominasi Air perlu dilakukan sedini mungkin untuk menghindari tekanandrop yang besar di awal produksi.

2. Natural recharge yang terjadi di reservoir dominasi air berjalan sangat lambat dibandingkan rate injeksi sehingga penurunan tekanan yang terjadi di reservoir lebih dipengaruhi oleh rate injeksi.

3. Decline yang kecil pada tekanan reservoir panas bumi dua fasa dominasi air memungkinkan sustainability reservoir yang lama, namun di sisi lain, steam cap tidak akan cepat terbentuk.

\section{Saran}

Pihak pengembang lapangan panas bumi menginginkan penurunan tekanan yang besar di awal masa produksi. Hal ini disebabkan oleh adanya pengembangan steam cap yang akan menguntungkan bagi proses produksi, yaitu bertambahnya produksi steam. Namun, penurunan tekanan yang besar dapat menyebabkan tekanan reservoir menjadi kecil dan fluida tidak dapat terangkat ke permukaan. Bahkan, dapat membuat sumur produksi mati. Untuk itu, perlu dilakukan strategi produksi yang tepat agar produksi optimal, namun sustainability reservoir juga terjaga.

\section{Daftar Pustaka}

Armstead, H.C.H., 1982.Geothermal Energy. E and FN Spoon Ltd., London City (reprinted).

Aziz K., Settari A., 1979. Petroleum Reservoir Simulation. Elsevier Apllied Science Publishers. Essex, England.

Chillinger, George V., 1982. Handbook of Geothermal Energy. Gulf Publishing Company: University of Southern California, Texas.

Crichlow, H.B., 1977. Modern Reservoir Engineering-A Simulation Approach.

Edward F. Wahl., 1977. Geothermal Energy System. Dept. of Scientific and Industrial Research: Chemistry Division Tarpo, Academic Press, New York.

Grant A. Malcolm., Donaldson G. Ian., Bixley F. Paul., 1982. Geothermal Reservoir Engineering. Academic Press Inc., New York. 
Pengaruh Sumur Injeksi Terhadap Reservoir Panas Bumi Dominasi Air pada Simulasi Lapangan Panas Bumi Dieng Unit II Menggunakan Software Tough-2

O’Sullivan, M.J. and McKibbin R.. 1987. Geothermal Reservoir Engineering, Course Material, Geothermal Institute - University of Auckland.
Whiting, R.L., Ramey, H.J. 1969. Application of Material and Kesetimbangan Energis to Geothermal Steam Production, Journal of Petroleum Technology. 